\title{
Handling, tekstualisering og tekst
}

\section{Ole Togeby}

Der argumenteres her for at talehandlinger og teksthandlinger er to forskellige typer af handlinger. En talehandling er situeringen af et udsagn om et sagforhold. En teksthandling er situeringen af helheden af en række forbundne paragraffer (som er degraderede udsagn) som udgør en beskrivelse af sagforhold. Talehandlingens type afhænger af konfigurationen af udsagnets realitetsværdi, emnetype og omsagnstype; teksthandlingens type desuden af den dominerende type af konneksionsrelationer mellem paragrafferne.

\section{Talehandlinger}

I beskrivelsen af talehandlinger (speech acts, sproghandlinger) kan alle vist blive enige om hvilken type talehandling følgende replik hører til:

\section{(1) Tusind Tak}

Det er en taksigelseshandling. Denne handling beskrives af John R. Searle (1969:67) således $(H=$ hearer, $S=$ speaker $)$ :

(2)

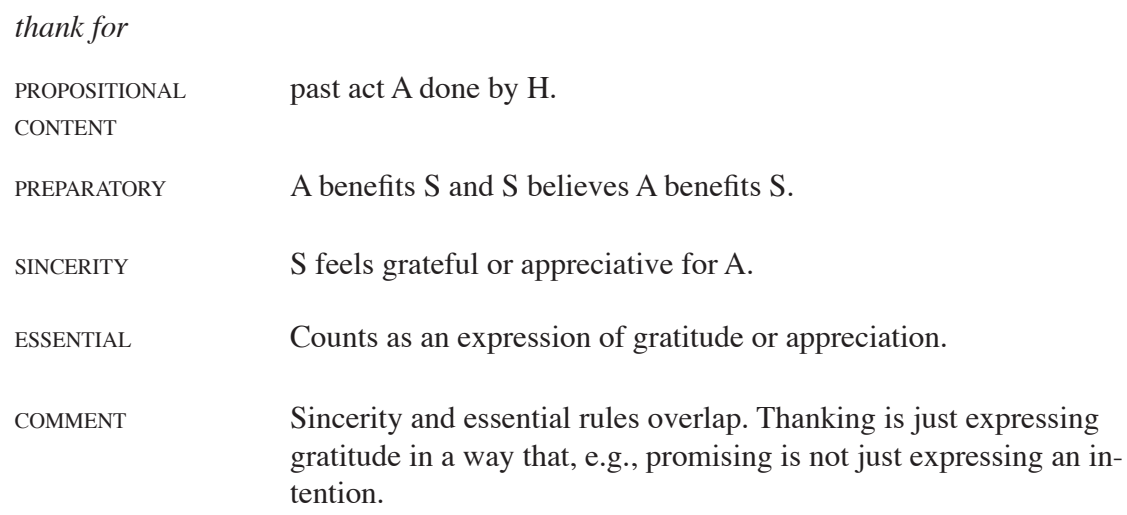




\section{Ole Togeby}

Jeg har to typer af kommentarer til denne beskrivelse: for det første at den ikke er helt præcis, og for det andet at den kan fremstilles i et bedre format.

Først skal det nævnes at der findes to former for tak, en der nærmest er en minimalt respons, og som udløses af et vaersgo eller det at den ene rækker den anden noget, $\mathrm{fx}$ at ekspedienten giver byttepengene tilbage, og så det store tak som er en egentlig ytring og dermed en talehandling. Searles beskrivelse af det store tak forekommer mig upræcis, for takke gør afsenderen A kun hvis det både er tilfældet at A er glad for modtageren Ms foregående handling $\mathrm{h}$ (Searles preparatory rule), og at $\mathrm{h}$ er udført af $\mathrm{M}$ som en gave, dvs. frivilligt, til glæde for A og uegennyttigt, med tab for M (og det gælder jo ikke byttepengene).

Takken må nødvendigvis bestemmes som det andet led i det som nogle kalder et ytringspar (adjacency-pair) der hører sammen ved at åbne og lukke en interaktionsenhed, fx spørge-svare, befale-adlyde, love-modtage løfte. Det er både uhøfligt og meningsbærende ikke at takke for noget som faktisk er en gave B hvad man kan høre forældre belære deres børn om juleaften. Taksigelse er altså en lukke-talehandling i et ytringspar. Der er et skær af gambit over gave-takke-parret: giveren "ofrer" sin gave for at opnå en mere langsigtet, men også uhåndgribelig fordel, nemlig goodwill fra gavemodtageren. Det er denne goodwill takkeafsenderen står inde for med taksigelsen.

Searles beskrivelsesformat er fra 1969, og de forhold som han taler om, har i løbet af de 40 forløbne år fået andre hævdvundne betegnelser. Jeg vil derfor her foreslå et format til beskrivelse af talehandlinger som har følgende poster: 1) SAGFORHOLDET, som er det der tales om (= propositional content), 2) de informationer der FORUDSÆTTES af formuleringen af sætningen, dvs. det der ofte kaldes præsuppositionerne (= preparatory-1), 3) hvilke informationer der er nye og INFORMATIVE for modtageren i situationen (= preparatory-2), 4) hvilke motiver, lyster, ønsker og interesser der er UNDERFORSTÅEDE, og som gør ytringen RELEVANT for parterne i situationen, det som af Grice beskrives som (generaliserede og partikulariserede) konversationelle implikaturer (= preparatory-3), 5) at det er afsenderens ÆRLIGE intention at den illokutionære kraft (det som ytringen tæller som) også skal have perlokutionær virkning (= sincerity), 6) hvad en ytring TÆLLER SOM i den sociale kommunikationssituation (= essential). Jeg vil altså foreslå at talehandlinger beskrives i følgende format: 
Handling, tekstualisering og tekst

(3)

\begin{tabular}{|c|c|}
\hline taksigelse & ( $\mathrm{A}=$ afsender, $\mathrm{M}=$ modtager, $\mathrm{Y}=$ ytring, $\mathrm{SF}=$ sagforhold $)$ \\
\hline SAGFORHOLD (SF) & As reaktion på Ms foregående handling $\mathrm{h}$. \\
\hline FORUDSÆTTELSER & $\begin{array}{l}\text { M har udført handlingen h over for A. } \\
\text { h er en gave, dvs. udført frivilligt, til glæde for A, og uden ve- } \\
\text { derlag. }\end{array}$ \\
\hline INFORMATIVITET & $\begin{array}{l}\text { det er ikke givet for M 1) at A har modtaget h, eller 2) at A er } \\
\text { glad for h. }\end{array}$ \\
\hline RELEVANS FOR M & M forventer reaktion fra A på handlingen $\mathrm{h}$. \\
\hline As ÆRLIGHED & A er faktisk glad for $\mathrm{h}$. \\
\hline Y TÆLLER SOM & $\begin{array}{l}\text { Y tæller som As udtryk for taknemmelig over Ms gave, og som } \\
\text { kvittering for modtagelsen af den. }\end{array}$ \\
\hline EKSEMPEL & Tusind Tak. \\
\hline
\end{tabular}

I eksemplet Tusind tak kan formlen udfyldes således: ytringen er en ekspressiv-regulativ talehandling hvormed afsenderen for det første udtrykker sin taknemmelighed over for giveren af en gave. Det propositionelle indhold af taksigelsen er altså ikke, som Searle ellers skriver, modtagerens tidligere gavegivningshandling (den er forudsat), men afsenderens taknemmelighed for den. Som en sekundær kvalitet skal taksigelsen også tjene som en kvittering til modtageren for modtagelse af gaven. Talehandlingen er primært ekspressiv og sekundært også regulativ. Det propositionelle indhold af (1) er således: "jeg er glad for det som jeg anerkender at du har gjort for mig".

\section{Bestanddelene i en talehandling}

\subsection{Entiteter afforskellig orden}

Talehandlingen består af situering, dvs. angivelse af den illokutionære kraft (I) for et udsagn, som selv består i udsigelse af realitetsværdien (R) af et sagforhold, som selv består af og et omsagn (prædikat) $(\mathrm{O})$ om forholdet mellem de emner (argumenter, subjekt og objekt) (E) som der henvises til: 


\section{Ole Togeby}

(4)

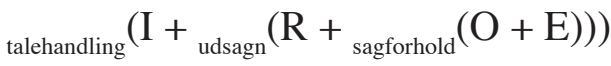

\begin{tabular}{|l|l|l|l|}
\hline situering & udsigelse & omsigelse & henvisning \\
\hline \multirow{2}{*}{$\begin{array}{l}\text { illokutionær } \\
\text { kraft: (tilpas- } \\
\text { ningsretning) }\end{array}$} & $\begin{array}{l}\text { realitet (nek- } \\
\text { sus, ordstil. } \\
\text { adv.) }\end{array}$ & omsagn (prædikat) & emner (argumenter) $1^{\circ}$ \\
\cline { 2 - 4 } & udsagn (med sandhedsværdi) $3^{0}$ \\
\cline { 2 - 3 } & sagforhold (med mening om sit) $2^{\circ}$ \\
\hline \multirow{2}{*}{ talehandling (med sociale konsekvenser i kommunikationssituationen) $4^{\circ}$}
\end{tabular}

$\mathrm{E}=$ emner, $\mathrm{O}=$ omsagn (prædikat), $\mathrm{R}=$ realitetsmark $\varnothing \mathrm{r}, \mathrm{I}=$ illokutionsmark $\varnothing \mathrm{r}$

Der kan på denne måde skelnes mellem entiteter af forskellig orden. Emner er entiteter af $1^{\circ}$, sagforhold entiteter af $2^{\circ}$, udsagn af $3^{\circ}$, og talehandlinger entiteter af $4^{\circ}$ (Reichenbach 1966: § 49, 53, Lyons 1977:kap 11.3).

Emner er den slags som de fleste simple substantiver henviser til, fx Stjernen Aldebaran, Josef, Potifars Hustru, Knappenaal, og som betegner håndgribelige ting, masser, dyr og personer (Togeby 2003: $\S \S 197-211)$. Emner kan have eksistens, men ikke vare ved eller vare sande. De kan fungere som rolleled (Togeby 2003: $\S$ 67-73) for materielle foregange som betegner processer, placering, adfærd og handling (Togeby 2003: §§ 212-218), fx falde ned, rakke, satte fast.

Sagforhold angives med en at-sætning, fx at jeg hedder Eniolo, at de betragtede ham, og betegner meningsfulde situationer med foregange og roller, tid og sted, men uden sandhedsværdi. Sagforhold kan foregå på bestemte måder (Togeby 2003: 220-226), fx langsomt, alvorligt, behageligt, og være genstand for mentale foregange, fx sagde, så, synes, og være årsager til andre sagforhold.

Udsagn angives med helsætninger, fx Giovanni, som saa, at de betragtede ham, kom hen til dem, eller Giovanni udtrykte sin Taknemmelighed for den Venlighed, hun havde vist ham, eller nominaliseringer i bestemt form, fx den Venlighed hun havde vist ham. Udsagn kan være genstand for foregange der betegner vurdering, ytring og regulering, $\mathrm{fx}$ Det er en god gammel tanke at ....

Talehandlinger er historiske begivenheder som kan dokumenteres med tid sted og personer. 


\section{Handling, tekstualisering og tekst}

\section{Entitetstyper}

$\begin{array}{llll}\text { Ent } & \text { type } & \text { materiale } & \text { prædikat der tager } \mathrm{E}^{\mathrm{x}} \text { som argument } \\ 1^{\circ} & \text { emne } & \text { nominal } & \text { materielle foregange } \\ 2^{\circ} & \text { sagforhold } & \text { at-sætning } & \text { mentale foregange, mådesadverbier } \\ 3^{\circ} & \text { udsagn } & \text { helsætning } & \begin{array}{l}\text { modalvb, sandt, muligt, sandsynligt, udsagns- } \\ \text { adverbier }\end{array} \\ 4^{\circ} & \text { talehandling } & \begin{array}{l}\text { ytring i en si- } \\ \text { tuation }\end{array} & \text { indikativ, imperativ, optativ, attitudeadverbier }\end{array}$

Hver af de fire elementer i talehandlingen: illokutionær kraft, realitetsværdi, emner, omsagn, har sit paradigmatiske rum. Handlingens illokutionære kraft kan være konstativ, ekspressiv eller normativ. Realitetsværdien kan være fremsat, benægtet, spørgende, hypotetisk eller ironisk. Henvisningen til et emne kan være deiktisk, historisk, generisk eller på skrømt (fiktiv). Omsagnet kan være objektivt, subjektivt eller normativt.

\subsection{Illokutionaer kraft}

De fleste talehandlingsteoretikere inddeler talehandlingerne efter deres illokutionære kraft, dvs. efter hvad ytringen tæller som i interaktionen med andre sprogbrugere, om afsenderen står inde for 1) at sagforholdet i sætningen svarer til virkeligheden, 2) at virkeligheden svarer til sagforholdet, eller 3) ingen af delene (direction of fit, Searle 1976).

Ytringen af sætninger (med objektive omsagn) som afsenderen står inde for sandheden af, kaldes KONSTATIVE TALEHANDLINGER. Ytringen af sætninger (med normative, omsagn) som afsenderen står inde for retmæssigheden af, kaldes REGULATIVE TALEHANDLINGER. Ytringer af sætninger (med subjektive omsagn) som afsenderen står inde for ærligheden af, kaldes EKSPRESSIVE TALEHANDLINGER. Talehandlingstyperne kan underinddeles på følgende måde (Arndt 2007, Habermas 2001, Searle 1969, Searle 1976):

1. Konstative, sagforholdet skal passe til verden:

a. oplyse (relevans): Hun er kommet

b. hævde (sandhed): Jordens temperatur har varet stigende $i$ de sidste 10 år

c. antage (troværdighed): Hun kommer nok tilbage, for hendes taske står her 


\section{Ole Togeby}

2. EKSPRESSIVE, udsagnet åbenbarer As ønsker, hensigter, følelser, vurderinger og tilbøjeligheder:
a. estimeringer: Det er koldere end $i$ køleskabet
b. evalueringer: Det er hundekoldt
c. emotiver (intransitive vb): Jeg fryser

3. Regulative, verden skal passe til sagforholdet, retmæssighed:

a. direktiver (Ms handling): Kom herhen!

b. kommissiver (As handling): Jeg lover at komme med det samme.

c. aftaler (gensidige handlinger): Vi modes $k l .16$

d. regler (generelle): Man må ikke slå på en der er mindre end en selv

e. erklæringer (skaber og ændrer sociale institutioner): Jeg erklarer hermed konferencen for åben.

\subsection{Realitetsvardi}

Realitetsværdi er noget som udsigelsen om et sagforhold kan have, og angiver om sagforholdet svarer til virkeligheden og er sandt, eller ikke svarer til virkeligheden og er falsk. Men realitetsværdien af det sagforhold som en sætning er om, kan også være spurgt om, hypotetisk, kontrafaktisk eller ironisk.

Realitetsværdien signaleres af afsenderen hovedsageligt ved grammatiske midler, dvs. ordstilling i neksusforbindelsen, udsagnsadverbier, konjunktioner, tempusendelser og pronominer.

Paradigmet for realitetsværdi ser således ud:

FREMSAT (sandt): Hun er kommet

BENÆGTET (falsk): Hun er ikke kommet

SPØRGENDE: Kommer hun?

HYPOTETISK: Hvis hun kommer, går jeg

KONTRAFAKTISK: Hvis hun kom, ville jeg gå

IRONISK: Alle får ligelфn og månen er lavet af en grøn ost.

\subsection{Emneforankring}

Sagforholdet, som er omsagnet om emnerne i den omtalte situation, har ikke i sig selv nogen realitetsværdi i kommunikationssituationen, men er netop kun omtalt. Den omtalte situation er den opfattede mening med udsagnene som er fælles for parterne, det som begge parters tanker er om, det fælles fænomenologiske indhold. Kommunikation ved hjælp 


\section{Handling, tekstualisering og tekst}

af sprog kommer i stand ved at afsenderen henviser modtagerne til elementer i den omtalte situation, som derved forankres til kommunikationssituationens virkelighed. (Mit ord henvisning er en dansk betegnelse for det der de fleste steder kaldes reference. Jeg bruger ikke ordet reference fordi det er systematisk flertydigt på flere dimensioner, og derfor vil give en masse sprogforbistring. Til gengæld vil jeg nu definere begrebet 'henvisning' omhyggeligt.) Denne henvisning kan ske på en af fire forskellige måder:

DEIKTISK (afsenderrelativ) henvisning:

Den omtalte situation er identisk med kommunikationssituationen; afsenderen konstituerer og regulerer sociale relationer mellem afsender og modtagere ved endocentrisk henvisning, dvs. henvisning relativt til et definerende element (JEG, DU, HER, HERMED) i kommunikationssituationen, $\mathrm{fx} G a ̊$ din vej! eller Jeg lover hermed at betale pengene tilbage $\underline{i \text { morgen. }}$. Herunder hører de ytringer som kaldes performativer, dem hvor man gør noget ved hjælp af ord.

HISTORISK (absolut) henvisning:

Den omtalte situation og kommunikationssituationen er adskilt $i$ tid eller rum; og ved at henvise ABSOLuT (dvs. i forhold til eksterne kendsgerninger om tidsregning og geografi som antages kendte og givne for parterne) til et element (x) i den omtalte situation forankrer afsenderen den til kommunikationssituationen, $\mathrm{fx}$ Michelle Obamas tiptipoldemor var slave $i$ Sydstaterne - og 475 dollar vard (Politiken søndag 11. oktober 2009:I,9).

FIKTIV henvisning:

Den omtalte situation er adskilt fra kommunikationssituationen uden at være forankret til den; den omtalte situation er en metafor for den virkelighed som kommunikationssituationen er en del af; eventuelle henvisninger og forankringer sker PÅ SKRøMT, fx Der stod et ildsprudende Bjerg $i$ Skovene, med sit sorte arrede Hoved ovenud af Skyerne, ved dets Fod voksede der Palmer; det var $i \underline{\text { de }}$ varme Aartusinder med endnu evig Sommer for Istiden (Johannes V. Jensen 1938: Gunnung Api, Den lange Rejse).

GENERISK henvisning:

Fremstillingen i tegnet er på grund af generelle henvisninger en beskrivelse af lovmæssigheder i virkeligheden og omfatter som sådan også kommunikationssituationen, fx Silkehalen lever mest af kфdbar og rфnnebar. Den har aldrig ynglet i Danmark. Silkehalen kan rejse hovedtoppen lige $i$ vejret eller lagge den naesten helt ned, 
Ole Togeby

som det passer fuglen bedst. (Hans Hvass 1954: Fugle i farver. Politikens Forlag:144)

(5)

Fire former for henvisning

deiktisk henvisning

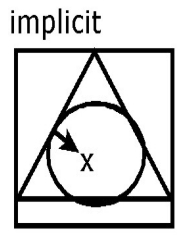

eksplicit jeg

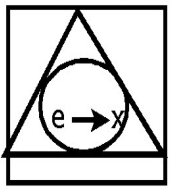

historisk henvisning

fiktiv henvisning
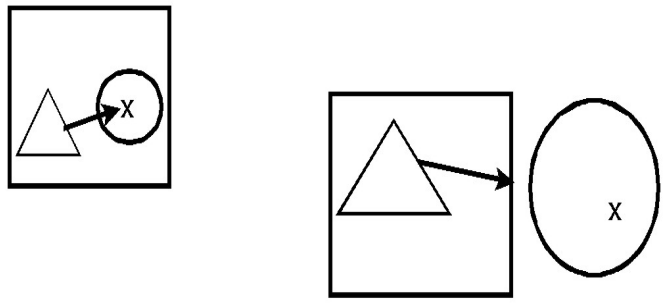

generisk henvisning

virkeligheden

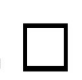

kommunikationssituationen $\triangle$

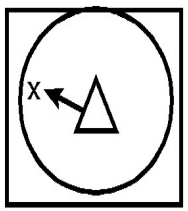

den omtalte situation

henvisning til et element $\mathrm{i}$ den

fremstillede situation

\subsection{Typer af omsagn}

På tværs af realitetsværdien i udsigelsen af sagforholdet kan omsagn inddeles i objektive, subjektive og normative typer.

ET OBJEKTIVT OMSAGN er et udsagn hvor afsenderen taler om 3. personsforhold, dvs. elementer i den omtalte situation (af hvad art den end er) under forudsætning af at hun eller han ved eller med overbevisning antager noget om den, og så med udsagnet orienterer eller oplyser modtagerne om den.

Et objektivt omsagn kan kendes på at man ikke efter det kan tilføje et: - synes jeg; det lyder ikke rigtigt at sige *Silkehalen lever af rønnebar, synes jeg. Adjektiver der ikke kan gradbøjes angiver som regel noget objektivt, fx kommunal, femkantet, elektrisk. Objektive omsagn handler om hvilke kategorier personer, genstande, foregange og forhold 


\section{Handling, tekstualisering og tekst}

hører til, og om handlinger og begivenheder finder sted, og de kan være sande, falske eller sandsynlige.

Et subJeKTivT OMSAGN er et hvor afsenderen ud fra et 1. personsperspektiv synes noget om noget og giver udtryk for det, dvs. forholder sig til, tager stilling til, estimerer, vurderer, evaluerer noget, som i øvrigt forudsættes kendt af modtagerne. Subjektive udsagn er observatørafhængige (de er afhængige af hvem der er observatøren af sagforholdet), og to observatører behøver ikke at være enige; den ene kan synes at der er varmt, den anden at der er koldt. Subjektive omsagn kan derfor ikke være sande og falske som de objektive; de udtrykker blot afsenderens subjektive stillingtagen; de kan kun være ærlige og oprigtige eller forstilte og hykleriske.

Subjektive omsagn kan kendes på at man efter dem godt kan sætte et - synes jeg, fx ... det er komisk, synes jeg. Subjektivitet udtrykkes ofte ved adjektiver (og deraf afledte adverbier) der kan gradbøjes, fx dyr, almindelig, god, gammel, ved deres fulde fem, ved vurderende substantiver som fx en taber, idiot, klovn, guttermand, ved ytringsadverbier der markerer vurdering: beklageligvis, desvarre, sjovt nok.

ET NORMATIVT OMSAGN er et der fokuserer på det sociale forhold mellem 1. og 2. person, og udsteder en norm for det (og eventuelt også for andre mennesker). Et normativt omsagn handler om hvad parterne vil og $\emptyset$ nsker, og hvad de kan, skal, må og bør. Normative omsagn kan ikke være sande eller falske som de objektive, og ikke oprigtige eller hykleriske som de subjektive, men retmæssige og gyldige eller uretmæssige og ugyldige.

Et normativt omsagn kan kendes på imperativform af verbet, eller på modalverberne skulle, måtte, kunne, ville, burde. Konklusionen i argumentation opfatter jeg her som normativ fordi meningen med konklusionen er over for modtagerne at sige: 'det bør I acceptere som rigtigt'.

I logik er der en tradition for at skelne mellem deskriptive og normative omsagn; det er blot en mere grov inddeling end den her foreslåede, hvor alle objektive omsagn er deskriptive, alle normative omsagn normative, og subjektive omsagn opfattes som normative der forudsætter et objektivt omsagn om samme emne. Det er et vigtigt skel i logikken fordi man ikke kan slutte fra noget deskriptivt, til noget normativt, ikke fra hvordan ting er, til hvordan de bør være (undtagen det der beskrives er en talehandling). 


\section{Ole Togeby}

\section{Teksthandlinger}

Den der har sagt replikken (1), afsenderen, er i dette eksempel Potifars hustru, hende fra 1. Mosebog 39, og modtageren er Josef, Jakobs søn. Og som man videre kan se, er alle betingelserne opfyldt og talehandlingen vellykket. Ytringer kan kun tælle som illokutionære talehandlinger i KOMMUNIKATIONSSITUATIONER, med specifikke AFSENDER, MODTAGERE. Talehandlinger kan derfor kun beskrives som begivenheder af en historiker eller observatør til кommunikationssituationen. Sagforholdet (As taknemmelighed til $\mathrm{M}$ ) er i modsætning hertil en OMTALT SITUATION. I takkeeksemplet er den omtalte situation så den samme som kommunikationssituationen, udsagnet handler om kommunikationssituationens personer og deres aktuelle tid, men det er ikke altid tilfældet, fx ikke i Hun sagde tak.

(1) er imidlertid en del af en større tekst:

da Stjernen Aldebaran faldt ned fra sin Bane paa Himlen, tog [jeg] den op og rakte Dem den. ${ }_{2}$ De satte den fast i Deres Fichu med en Knappenaal og sagde: ${ }_{31}$ Tusind Tak, Joseph."

Sætningsemnet Tusind Tak er altså ikke en virkelig takketalehandling, men emne i et udsagn $i$ anden ytring (en tekst) med omvendte interaktionsroller (Josef er afsender og Potifars hustru modtager, og en fichu er et tørklæde). ${ }_{21}$ De satte den fast $i$ Deres Fichu med en Knappenaal og sagde:»Tusind Tak, Joseph.«, er en konstativ talehandling med fremsat realitetsværdi som Searle beskriver således:

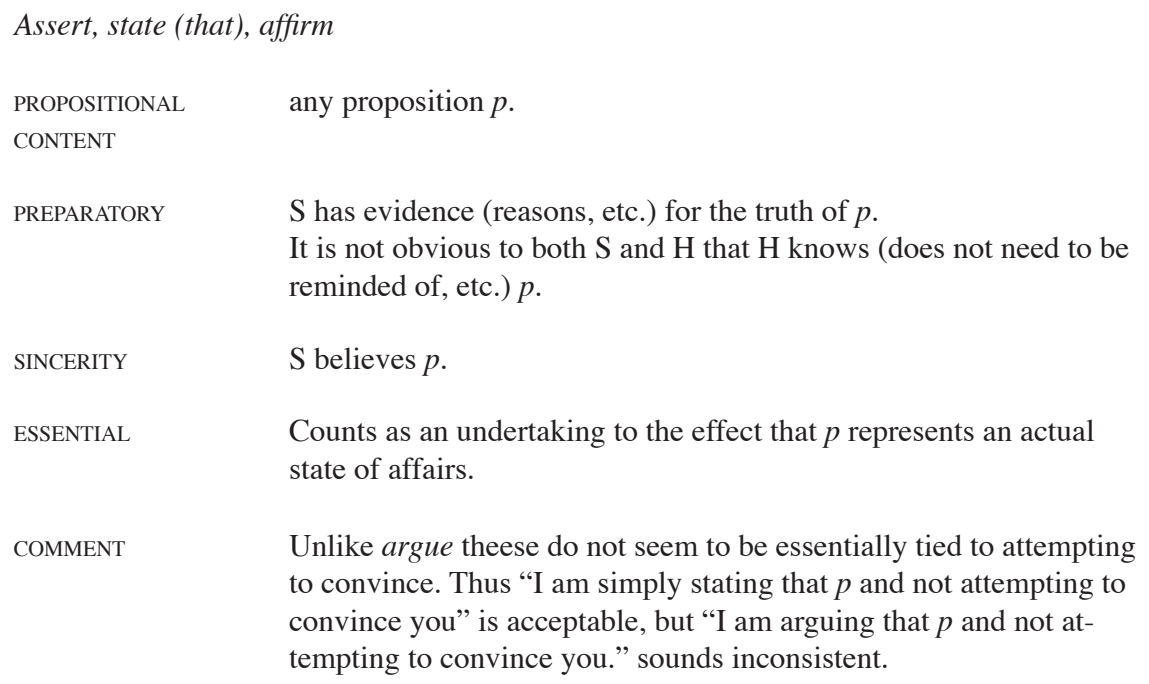


Og som jeg vil beskrive den:

(8)

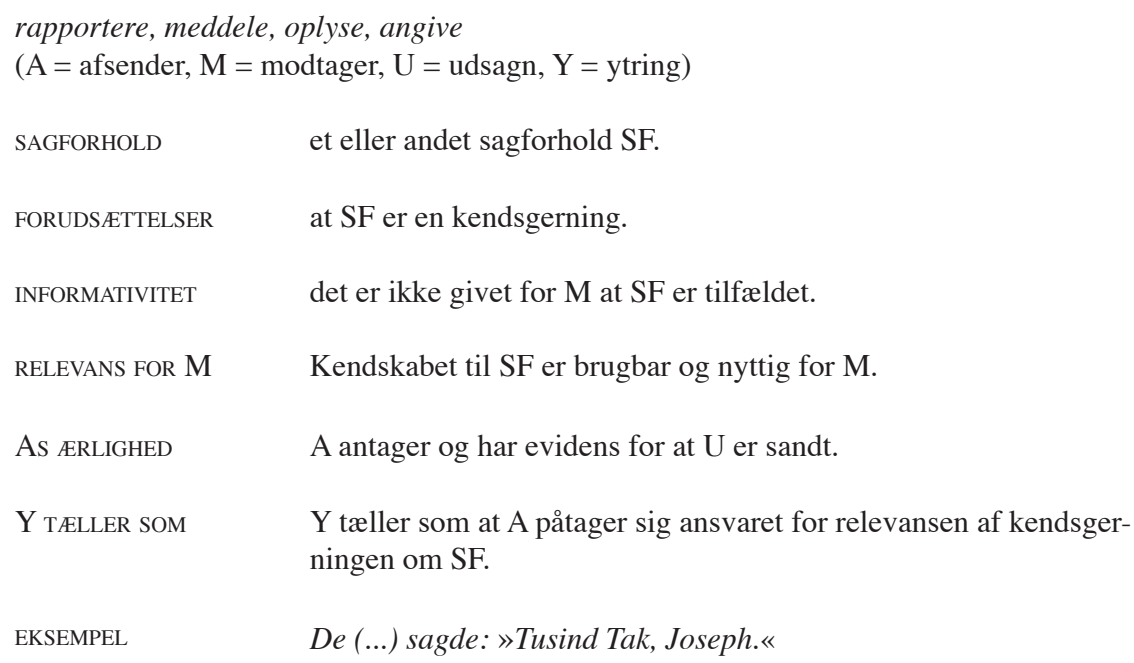

Jeg har her valgt en anden essentiel betingelse end Searle, således at talehandling 'at oplyse' ikke tæller som en forpligtelse for afsenderen på sandheden, men en forpligtelse på relevansen af det sagforhold som afsenderen nemlig forudsætter er sandt. Talehandlingen 'hævde', 'påstå' er omvendt en hvor afsenderen forpligter sig på at fremlægge evidenser for at sagforholdet er sandt, mens relevansen er sekundær og blot forudsættes. Oplyse og hævde er således to underafdelinger af konstative talehandlinger.

Sætning $2 \backslash$ i (6) er integreret i en tekst der først beskriver Josefs gave til Potifars hustru og dernæst hendes tak for gaven. Man ser altså at betingelserne for hendes takkehandling er til stede i dens egen kommunikationssituation, den som beskrives i tekst (6).

De tre sætninger må som helhed beskrives som tekstualiserede, dvs. forbundet med konneksionsangivelser og dermed integreret med hinanden til en helhed der henviser til det samme sagforhold, nemlig en replikudveksling i den samme omtalte situation med de samme personer. Det er ikke tre talehandlinger der i kommunikationssituationen er stillet efter hinanden med det logiske konnektiv 'og' imellem, men tre sagforhold som i den omtalte situation er forbundet med bestemte relationer. $1 \backslash$ og $2 \backslash$ er forbundet med en derefter:-relation (signaleret ved sætningernes rækkefølge), og det er klart at sagforholdet i $2 \backslash$ forudsætter sagforholdet i $1 \backslash$, og at de derfor må høre til samme handling og 


\section{Ole Togeby}

have samme realitetsværdi, samme emneforankring, men kun forskellige omsagnstyper. Sagforholdene i de to sætninger er FUSIONERET med hinanden til et sagforhold, som to klumper modellervoks der æltes sammen til én.

Sætning $2 \backslash$ og $3 \backslash$ er forbundet med en at:-konneksion som er signaleret med kolon og anførselstegn. Denne konneksion gør at $3 \backslash$ mister sin illokutionære kraft og sin realitetsværdi; pronominerne, som også kan kaldes skiftere, skifter betydning, så 1. person i 3\ er Potifars hustru, mens 1. person i 1\-2 $\backslash$ er Josef. at:-konneksionen mellem $2 \backslash$ og $3 \backslash$ betyder også at der ikke kan tilskrives illokutionær kraft, realitetsværdi og emnestatus til $3 \backslash$ uafhængigt af $2 \backslash$. Realitetsstatus tilskrives ikke takkehandlingen, men rapporten om takkehandlingen. at:-konneksionen degraderer takkehandlingen $3 \backslash$ til et emne i den omtalte situation. Den form for integration der sker mellem meningen med sætningerne $3 \backslash$ og 2\, kan bedst beskrives som INKORPORERING, sådan som en lille babushkadukke er lukket inde i den større dukke, og ikke selv kan ses mere. Det skyldes at omsagnet i $2 \backslash$ sagde er et anførende prædikat som angiver logiske typer, dvs. at det ene prædikat er metaudsagn om det andet.

Realitetsværdien for sætning $1 \backslash$ og $2 \backslash$ kan det være svært at bestemme; hvordan kan en stjerne falde ned fra himlen, og hvordan kan Josef derefter samle den op? Det tyder på at den ikke er fremsat som sand, men det er ikke signaleret, og derfor må henvisningerne i (4) opfattes som fiktive; henvisningen til stjernen Aldebaran sker med andre ord på skrømt. Særlig underligt er det at denne fiktion handler om kommunikationssituationens parter, men i fortid.

Når $3 \backslash$ er inkorporeret i $2 \backslash$ (som en babushkadukke) og $1 \backslash$ og $2 \backslash$ er fusioneret med hinanden (som modellervoks) så de udgør ét sagforhold, må man sige at (6) ikke udgør en talehandling, men en TEKSTHANDLING fordi de tre sætninger gennem tekstualisering ved hjælp af konneksioner er blevet integreret i hinanden.

Men også denne teksthandling er et del af noget større:

(9)

${ }_{1}$ Madame, (...) ${ }_{21}$ der var, for lange siden, en Tid i mit Liv, da jeg var i Fangsel. ${ }_{31}$ Der kunde jeg ikke se Stjernerne, ${ }_{4}$ men jeg drømte om dem. - ${ }_{5} J e g$ drømte, at ${ }_{0}$ fordi jeg ikke var der til at holde Øje med dem, løb de uden Orden hid og did paa Himlen, saa at Faarehyrderne foer vild med deres Hjorder paa Bjergene, og Kameldriverne i Ørkenen. ${ }_{\lambda}$ Jeg drømte endogsaa om Dem, ${ }_{81} \mathrm{Ma}-$ dame, og at ${ }_{1}$ jeg, da Stjernen Aldebaran faldt ned fra sin Bane paa 
Himlen, tog den op og rakte Dem den. ${ }_{10}$ De satte den fast $i$ Deres Fichu med en Knappenaal og sagde: ${ }_{11} \gg$ Tusind Tak, Joseph." ${ }_{12}$ Det glader mig af Hjertet, at min Drøm nu paa en Maade gaar $i$ Opfyldelse. ${ }_{13}$ Den Orden, som De фnsker for Deres Svigers $\emptyset n$, er allerede bevilget ham.

Det viser sig i tekst (9) at tekst (6) = (9) 9-11 \er en refereret drøm, og således ganske rigtigt en form for fiktion. Men denne drøm 6-11 \er blot en der bliver genfortalt af Josef til Potifars hustru som begrundelse for at han bevilger en orden til hendes svigersøn, 13\. Hele (9) kan beskrives som én teksthandling med budskabet $13 \backslash$, som er den regulative talehandling en bevilling. Konneksionsrelationen mellem $12 \backslash$ og $13 \backslash$ er argumentationskonneksion som kan noteres ERGO:; Josef giver ordenen til svigersønnen fordi den gamle drøm derved går i opfyldelse. Og konneksionen mellem 1-11 $\backslash$ g de integrerede 12-13 $\backslash$ er en inkorporering.

$E R G O:-k o n n e k s i o n e n$ mellem $12 \backslash$ og $13 \backslash$ er hverken en fusion mellem to sagforhold eller en inkorporering af det ene sagforhold i det andet, men en KOMPOSITION af to udsagn (ikke blot deres sagforhold), hvor gyldigheden af konklusionen i 13\ er afhængig af sandheden og relevansen af 12\. Dette er som at bygge et højt tårn af klodser; den $\varnothing$ verste klods kan kun være hvor den er, på grund af tilstedeværelsen og placeringen af de andre klodser. Det er rationalet i argumentation: gyldigheden af konklusionen er afhængig af eksistensen og placeringen af argumenterne.

Som beskrevet består beretningen om og beskrivelsen af drømmen af omtalte verdener inkorporeret i hinanden; den inderste dukke er Tusind Tak, og det er netop det der er kernen i argumentationen, Josef bevilger ordenen fordi Potifars hustru i drømmen sagde tak.

\section{Teksthandlingers bestanddele}

\subsection{Simple og sammensatte ytringer}

TEKSTHANDLINGER (med egne meddelelser), som består af flere sætninger sat efter hinanden med angivelse af konneksionsrelationerne mellem dem, kan ikke siges at bestå af flere talehandlinger. Når det der kunne være flere talehandlinger, sættes sammen til en tekst, må nogle af udsagnene degraderes til at være underordnede hjælpeudsagn i forhold til andre udsagn som i modsætning hertil meddeler hele tekstens budskab. Michail Bachtin (2009) har udkastet ideen til en teori om simple og sammensatte talegenrer: 
(10)

Særlig vigtigt er det at rette opmærksomheden mod en meget væsentlig forskel mellem de primære (simple) og sekundære (sammensatte) talegenrer (...) Under krystalliseringsprocessen indoptager og bearbejder de sekundære genrer forskellige primære (simple) genrer, som har formet sig under det umiddelbare verbale samvær. Disse primære genrer transformeres og ændrer karakter, når de indgår i korpusset af sammensatte genrer.

Jeg vil her prøve at konkretisere Bachtins ide således at simple talehandlinger degraderes til paragraffer når de indgår i de komplekse teksthandlinger.

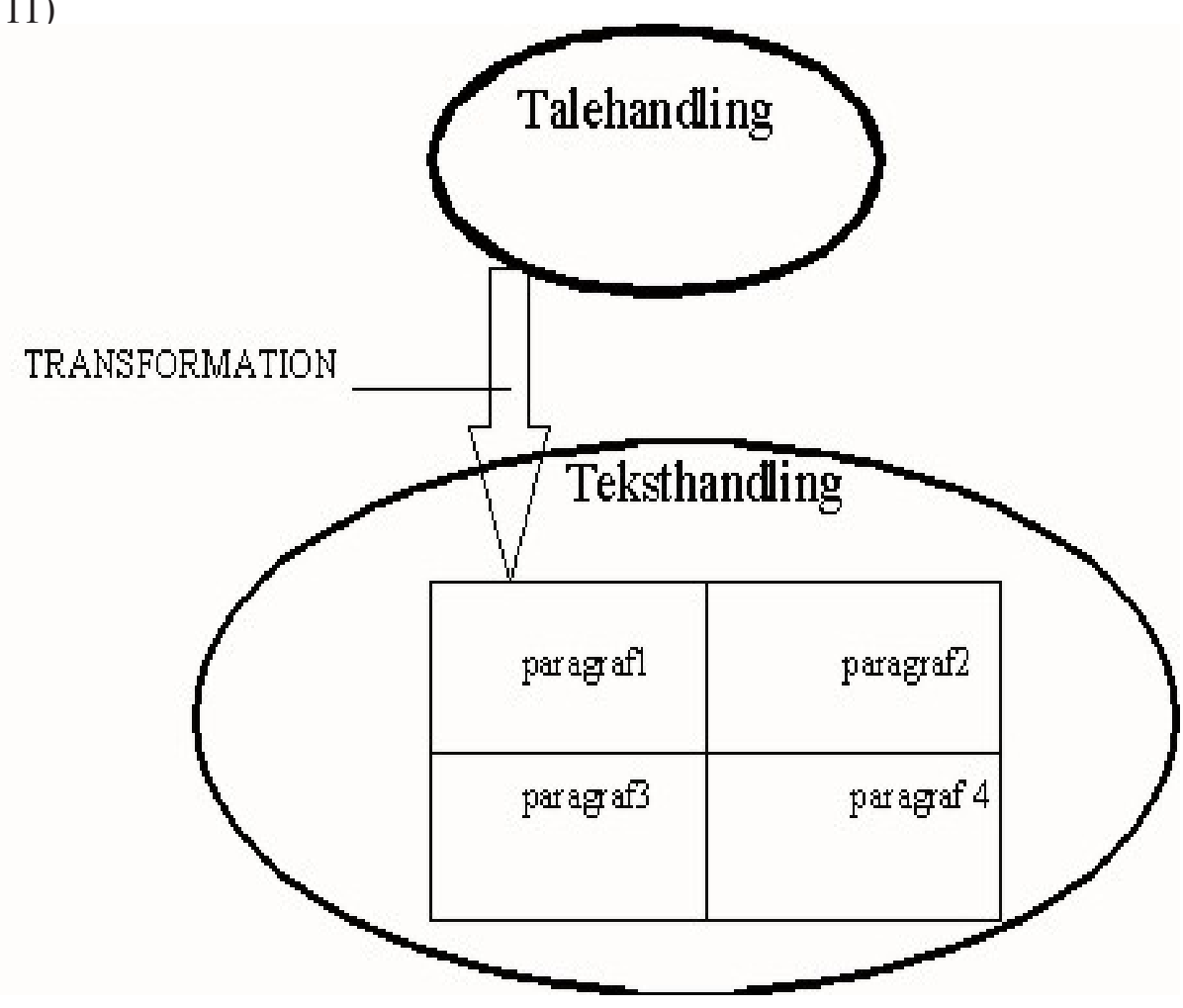

En teksthandling kan således beskrives som bestående af den illokutionære situering af en tekst, som er rækken af tekstualiserede paragraffer (som hver især er degraderede udsagn) der består af realitetsmarkerede sagforhold, som består af omsagn om emner. 
Handling, tekstualisering og tekst

(12)

tekathandling $\left(\mathrm{I}+{ }_{\text {tekst }}\left(\mathrm{K}+{ }_{\text {paragraffer }}\left(\mathrm{R}+{ }_{\text {sagforhold }}(\mathrm{O}+\mathrm{E})\right)\right)\right)$

\begin{tabular}{|l|l|l|l|l|}
\hline situering & tekstuering & udsigelse & omsigelse & henvisning \\
\hline \multirow{2}{*}{$\begin{array}{l}\text { Illokutionær } \\
\text { kraft }\end{array}$} & $\begin{array}{l}\text { Konneksioner } \\
\text { (konnektiver og } \\
\text { adverbier) }\end{array}$ & Realitet & Omsagn & Emne \\
\cline { 3 - 5 } & & \multicolumn{3}{|c|}{ paragraf (degraderet udsagn ) } \\
\cline { 3 - 5 } & \multicolumn{4}{|c|}{ tekst } \\
\hline \multicolumn{4}{c}{ teksthandling } \\
\hline
\end{tabular}

$\mathrm{E}=$ emner, $\mathrm{O}=$ omsagn, $\mathrm{R}=$ realitetsmark $\varnothing \mathrm{r}, \mathrm{I}=$ illokutionsmark $\varnothing \mathrm{r}, \mathrm{K}=$ konnektor.

Det er i dette eksempel klart at det hele er en replik i en situation med en samtale mellem Josef og Potifars hustru:

»Prins, « sagde hun, »dengang da Joseph var Premierminister i Agypten, og Potiphars Hustru en gammel Dame, søgte hun Audiens hos ham for at bede om den høje agyptiske Orden, "Paradisets Stjerne«, til sin Svigers $\phi n$. - »Jeg vil overmaade nфdig synes paatrangende, « sagde hun, »men det er jo nu saa lange siden, jeg sidste Gang bad Deres Excellence om noget. Maaske vil De denne Gang laane mig et venligt Øre.«

"Madame." svarede Premierministeren hende, »der var, for lange siden, en Tid $i$ mit Liv, da jeg var $i$ Fangsel. Der kunde jeg ikke se Stjernerne, men jeg drømte om dem. - Jeg drømte, at fordi jeg ikke var der til at holde Øje med dem, løb de uden Orden hid og did paa Himlen, saa at Faarehyrderne foer vild med deres Hjorder paa Bjergene, og Kameldriverne i Ørkenen. - Jeg drømte endogsaa om Dem, Madame, og at jeg, da Stjernen Aldebaran faldt ned fra sin Bane paa Himlen, tog den op og rakte Dem den. De satte den fast $i$ Deres Fichu med en Knappenaal og sagde: " $\underline{\text { Tusind }}$ Tak, Joseph." - Det gloeder mig af Hjertet, at min Drøm nu paa en Maade gaar i Opfyldelse. Den Orden, som De фnsker for Deres Svigers $\emptyset$, er allerede bevilget ham.«« 


\section{Ole Togeby}

\subsection{Karen Blixens fortcelling}

Den hun som fortæller denne historie, er Agnese della Gherardesca, og den prins som hun fortæller historien, er Giovanni Gastone (Nino). Sætningen sagde hun, røber at også dette er rapporterede begivenheder som fortælles fra den særlige synsvinkel som grev Augustus von Schimmelmann har (at synsvinklen er hans røbes af at Agnese andetsteds, når han tror at hun er en mand, omtales med ordet han, men med hun da han finder ud af at hun er en kvinde). De er alle sammen personer i Karen Blixens novelle Vejene omkring Pisa, som igen er den første fortælling i hendes Syv fantastiske fortcellinger fra 1935. Kommunikationssituationen har altså Karen Blixen som afsender, og det litterære danske publikum, herunder os, som modtagere.

Takketalehandlingen indgår altså som den inderste dukke i en russisk Babushkadukke med én stammoder og døtre i 5 generationer.

Karen Blixens første fortælling i Syv Fantastiske Fortcellinger, 1935

[Augustusfarvet fortælling af begivenhederne [Agneses fortælling til Giovanni (prins Nino)

[Josefs fortælling til Potifars hustru

[Josefs drøm

[Potifars hustrus tak]]]]]

Men hvad er da funktionen af denne inderste babushka, (1), i forhold til stammoderen, Karen Blixen og den litterære offentlighed? Hvad skal vi læsere af Karen Blixens novelle med oplysningen om denne takkehandling? Vi skal bruge den for at forstå den næste babushka, som vi skal forstå for at forstå den næste osv. Det der i sig selv er en taksigelseshandling, bliver i det øjeblik det bliver inkorporeret $\mathrm{i}$ en større tekst (6) De satte den fast i Deres Fichu med en Knappenaal og sagde: »Tusind Tak, Joseph.«til komplementet til en sætning der tæller som en oplysning om hvad "De" gjorde i drømmen. Og her er det som argumentet for at han giver ordenen til hendes svigers $\varnothing$.

Hvad er da budskabet i Josefs fortælling til Potifars hustru? Det er at de to har gennemført ytringsparret gave-taksigelse. I situationen har hun ansøgt om noget og han bevilger hende det, åbenbart fordi han har drømt at hun takker. Josef fortæller om sin drøm for at begrunde at han giver ordenen til hendes svigers $\emptyset$, selv om det nu er "saa lange siden, jeg sidste Gang bad Deres Excellence om noget. Maaske vil De denne Gang laane mig et venligt Øre." 
Læg mærke til at det med ordene sidste gang er forudsat information at hun har spurgt om noget en gang før, og med ordene denne gang at han den gang ikke gav hende hvad hun bad om. Det kan man kun forstå hvis man kender fortællingen i Første Mosebog 39, hvor Potifars hustru siger: Kom og lig hos mig! og Josef nægter.

Hvad er nu relevansen af at Agnese fortæller Nino historien om Josef og Potifars hustru? Det er jo ikke at man skal tro på Gud fordi han er almægtig (som vel i sidste ende er pointen i bibelen - og koranen hvor elementer af historien også fortælles). Agnese fortæller historien til Nino for at begrunde at hun netop har indvilget $i$ at være hans sekundant $\mathrm{i}$ en duel (Nino tror at hun er en mand fordi hun siger det og går $\mathrm{i}$ herretøj). Det fremgår af følgende ramme for historien:

[Agnese siger til Augustus] »Signore, « sagde hun langsomt og alvorligt, »jeg vil gerne gфre Deres Ven, Prins Giovanni, en Tjeneste og med stor Glade vare Sekundant ved denne Duel. Vore Familier har ikke staaet paa nogen god Fod med hinanden, men $i$ en Aressag er det jo vor Pligt at glemme gammelt Nag. Var saa god at sige Prins Giovanni, at jeg hedder Eniolo della Gherardesci og er hans arbødige Tjener.«

Giovanni, som saa, at de betragtede ham, kom hen til dem, og da Augustus forestillede dem, hilste de to unge Mennesker paa hinanden med den mest udsøgte Artighed. Hun stod med Ryggen til Scenen, og Rampelyset dannede en Glorie omkring hendes Hoved, saa at hun lignede en ung Engel, der for en Gangs Skyld optrader $i$ en Rolle som Kavaler. Tilskuerne, der havde varet ved at bryde op, genkendte Prinsen og stod stille for at se paa ham, idet de dog holdt sig i nogen Afstand fra den lille Gruppe.

Giovanni udtrykte sin Taknemlighed for den Venlighed, hun havde vist ham.

»Prins, « sagde hun, »dengang da Joseph var Premierminister $i$ Agypten, og Potiphars Hustru en gammel Dame, søgte hun Audiens (...)

Relevansen af Agneses historie er at der er parallelitet mellem den situation Agnese og Nino er i, og den situation henholdsvis Josef og Potifars hustru er i. Agnese leverer den ydelse at være sekundant for Nino, lige som Josef gav Potifars hustru medaljen til hendes svigersøn. Agnese skal altså identificeres med Josef, og følgelig skal Nino identificere 


\section{Ole Togeby}

sig med Potifars hustru (men har ikke forstået at det er det han skal). Og Nino takker da også, lige som Potifars hustru gør i historien: Giovanni udtrykte sin Taknemlighed for den Venlighed, hun havde vist ham. Dermed kan vi læsere ved parallelforskydning indse at Nino må have bedt Agnese om noget tidligere, og at hun har sagt nej. Og det er netop relevansen for os læsere af hele historien om Josef og Potifars hustru, at vi skal forstå noget om Nino og Agnese - noget som Augustus ikke forstår, selv om han hører (og videreformidler) selv samme historie. Det vi kan regne ud, er at Nino, da han første gang mødte hende i en kirke den gang da hun blev konfirmeret, til Agnese har sagt noget i retning af det Potifars hustru sagde til Josef første gang, nemlig mutatis mutandis: Må jeg komme og ligge hos dig? Og det er en meget væsentlig oplysning, for hele historien handler om forholdet mellem manden som gæst og kvinden som værtinde og diskuterer om det er rigtigt hvad Agnese hævder, nemlig at "En værtinde vil takkes". Med replikken anerkender Agnese således at Nino nu har takket - hvad han ikke gjorde da begivenheden fandt sted. Karen Blixens tekst er på denne måde både struktureret på babushkamaner og som en Mandelbrotfraktal, dvs. således at det er næsten det samme mønster man finder hele vejen ned. Det kaldes i den litterære kritik mise en abîme, sat i uudgrundelighed.

Det er lige præcis svaret på denne diskussion der er en del af den mening der kan findes i Karen Blixens Fortælling. Vi virkelige læsere af Karen Blixens historie, kan (ved parallelforskydning) identificere os med personerne i historien og derved opleve, glædes og lide som om vi var personer i historien og således komme rensede i sjælen ud af læsningen, det som kaldes katharsis.

Den nærmere sammenhæng i Karen Blixens historie kan ikke udredes her, men interesserede læsere henvises til Sørensen og Togeby (2001).

\section{Tekstkomposition}

\subsection{Kompositionsdiagram}

Tekstualisering består $\mathrm{i}$ at afsenderen ved at sætte udsagnene i rækkefølge, og ved sproglige signaler angiver hvilke konneksionsforbindelser (Togeby 2003:\$§ 97-133) der skal opfattes mellem dem. Det kræver at modtagerne har kendskab til hvilke konneksionsmuligheder der overhovedet kan komme på tale i den givne teksttype. Her skal der efter demonstrationen af en mulig tolkning af en kortere tekst, opstilles et inventar af mulige konneksioner. 


\section{Handling, tekstualisering og tekst}

(16)

${ }_{11}$ Hvem må slå hvem?

${ }_{21}$ Du må ikke slå på én der er mindre end dig selv. ${ }_{31}$ Det er en god gammel tanke. ${ }_{4}$ Hvis nu alle fulgte den, så havde man altid ret til at tove dem der var storre end en selv ( ${ }_{5}$ de må jo ikke slå igen). Det ville vare komisk, ${ }_{\lambda}$ men forelфbig har ingen set det realiseret, skønt alle børn har fået at vide at de ikke må slå på nogen der er mindre end dem selv. Satningen modsvares naturligvis af den sunde virkelighedssans som selv et barn hurtigt udvikler: ${ }_{9}$ Det kan ikke betale sig at slå på én der er større end en selv, ${ }_{10}$ for så får man bare tov. ${ }_{1 \Lambda}$ Man kunne også have udviklet følgende mundheld: ${ }_{12}$ Du må ikke slå på nogensomhelst! - ${ }_{131}$ Men det ville jo nok vare at gå for vidt at laere børn den slags.

Ole Grünbaum 1967: Provokér. Larestykker om den almindelige uorden. København: Hans Reitzels Forlag:30

${ }_{21}$ Du må ikke slå på én der er mindre end dig selv må isoleret opfattes som en regulativ talehandling af generel karakter, det som man kunne kalde en regel. Jeg går ud fra at $D u$ som i de 10 bud skal opfattes i betydningen 'man', således at reglen ikke kun gælder den tiltalte, men alle.

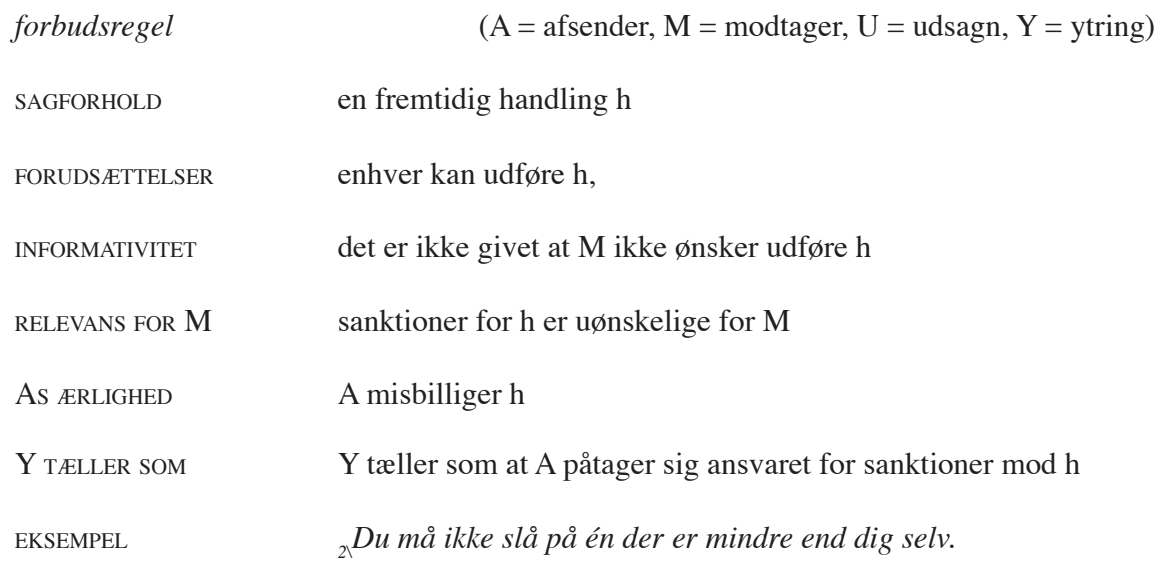

Denne regel er tekstualiseret ind i teksten som emne for prædikatet 'god gammel tanke' ved hjælp af anførselskonneksionen $\underline{S A G T \text { AF: }}$ (signaleret ved ordet Det) og er dermed på babushkamaner en del af en talehandling som kan parafraseres: 'Det er en god gammel tanke at du ikke må slå på én der er mindre end dig selv', og det er en ekspressiv talehandling af evaluativ type med afsenderen som evaluatøren. 


\section{Ole Togeby}

Der er imidlertid flere andre konneksioner på spil i denne tekst end anførselskonneksionen. Relationen mellem $4 \backslash$ og $5 \backslash$ er en argumentativ konneksion FOR: Forbindelsen mellem $2 \backslash-6 \backslash$ og $7 \backslash$ er en $\underline{M E N}:-$ konneksion, og forbindelsen mellem 2\-7\ og 8\-10 er (vel) årsagsrelationen $\underline{\text { FORDI}: ;}$; eksistensen af virkelighedssansen (det kan ikke betale sig at slå på én der er større end en selv) er årsagen til at ingen har set reglen i $2 \backslash$ realiseret. Og endelig er forbindelsen mellem $2 \backslash-8 \backslash$ og $11 \backslash-12 \backslash$ en ERGO:-konneksion. Det hele kan anskueliggøres i et diagram således:

(18)

${ }_{11}$ Hvem må slå hvem? $1 \backslash$

${ }_{21}$ Du må ikke slå på én NEMLIG:

der er mindre end dig selv. $\quad M$ : *

\section{SAGT AF:}

${ }_{31}$ Det er en god gammel tanke. $\frac{*}{3 \backslash} \quad *$

${ }_{4} \mathrm{Hvis}$ nu alle fulgte den, så havde man altid ret til at tæve dem der var større end en selv

${ }_{51}$ (de må jo ikke slå igen).

MEN:*
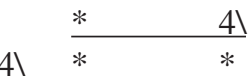

4

Det ville være komisk, FOR: * 4\

SAGT AF: * 5\}

${ }_{7}$ men foreløbig har ingen set det realiseret, skønt alle børn har fået at vide at de ikke må slå på nogen der er mindre end dem selv.

${ }_{81}$ Sætningen modsvares naturligvis af den sunde virkelighedssans som selv et barn hurtigt udvikler:

Det kan ikke betale sig at slå på én der er større end en selv,

101 for så får man bare tæv. 8 AT: $\quad * \quad 81$ 6\} $\underline{M E N}:$ $* \frac{7}{*}$ $7 \lambda$

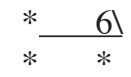
$10 \backslash$

111Man kunne også have udviklet følgende mundheld: $9 \backslash *$ $*$ FOR: * $\underline{E R G O}:$ ${ }_{221}$ Du må ikke slå på nogensomhelst! AT: $11 \backslash$ $12 \backslash$ ${ }_{13}$ Men det ville jo nok være at gå for vidt at lære børn den slags.

MEN:


Som tekst er (18), i modsætning til (Vejene omkring Pisa), domineret af argumentative konneksioner (FOR: og ERGO:) og har en argumentativ tekststruktur. Det som teksten argumenterer for, er ikke at en af de fire nævnte regler om hvem man må slå (nemlig: $2 \backslash$ man må ikke slå på en der er mindre, $4 \backslash$ man må gerne slå på en der er større, $9 \backslash$ det kan ikke betale sig at slå på en der er større og 12\ man må slet ikke slå) er bedre end de andre, men at $2 \backslash$ er det som børn får at vide, $4 \backslash$ er komisk og urealistisk, 9\er den børn følger, og 12\ er mulig, men at det ville være at gå for langt. Tekstens budskab i 13\ kan altså parafraseres: 'Det ville være at gå for langt at lære børn at man ikke må slå', og det er det der argumenteres for. Der er dog træk der tyder på at 13\ er et semicitat fra andre og derfor ironisk, således at meningen med hele teksthandlingen i sidste ende er at 'vi lever i et samfund med korrupte etiske regler'.

\subsection{Konneksioner}

Det ser ud til (som der også kun findes et begrænset antal underordningskonjunktioner) at der i vores tekstkultur kun findes et begrænset antal konneksionsforbindelser mellem udsagn. Læg mærke til at begrebet KONNEKSION er en indholdskategori som kan være udtrykt eksplicit ved hjælp af KONNEKTORER (især konjunktioner og adverbier) eller implicit ved hjælp af rækkefølge, relationerne mellem semantiske morfemer i teksten, genresignaler som tærskeltekster og signaler i situationen.

Konneksionsforbindelserne kan være generelle, anførende, narrative, argumentative eller informationelle. Universelle konneksioner SOm OG:, ELLER:, MEN:, LIGESOM:, ENDOG: kan findes i alle tekstualiseringsformer og kan indbyrdes forbinde både informationer om kommunikationssituationen og informationer om sagforholdet i den omtalte situation. Anførselskonneksionerne $\underline{A T:}$ : SAGT AF: er også universelle, men er særlige ved at forbinde logiske typer af forskellig orden; de indkorporerer sætninger som er potentielle entiteter af $4^{\circ}$ (talehandlinger), og degraderer dem til entiteter af $1^{\circ}$ (emner), således at de ikke længere indgår som enhed i tekstualiseringen.

Narrative konneksioner kan deles op i konneksioner om tid: $\underline{\text { SA:: }}$ MENS:; EFTER AT:, årsag: FORDI:, DERFOR:, hensigt: FOR AT:; VHJA:, og de strukturerer teksten alene efter relationerne i sagforholdet i den omtalte situation. Narrative konneksioner dominerer i beretninger og fortællinger.

Argumentative konneksioner som ERGO: FOR: er sammen med det generelle $\underline{M E N}$ : dominerende i argumentative tekstualiseringer (debatter, 


\section{Ole Togeby}

bedømmelser, begrundelser) og strukturerer teksten efter hvilke udsagn der som begrundelser i kommunikationssituationen kan overbevise modtagerne om sandheden af konklusionen.

Informationelle konneksioner som NEMLIG:, DVS: ALTSÅ:, KORT:; FX:, MULIGGØR: (M:), FORUDSAT: er dominerende i ekspositive tekstualiseringer (oversigter, forklaringer, nyhedsartikler) og strukturerer teksten efter hvilke informationer der for modtagerne er givne og hvilke nye (efter det generelle princip at givet skal før nyt, det væsentlige før det uvæsentlige).

Inventaret på konneksioner kan stilles op således:

\begin{tabular}{|c|c|c|c|}
\hline \multicolumn{2}{|l|}{ TYPE } & $\begin{array}{l}\text { KONNEKSIONS- } \\
\text { RELATIONER }\end{array}$ & $\begin{array}{c}\text { KONNEKTORER } \\
\text { (KONJUNKTIONER OG ADVERBIER): }\end{array}$ \\
\hline \multicolumn{2}{|c|}{$\begin{array}{l}\text { GENERELLE } \\
\text { LOGISKE } \\
\left(1^{\circ}\right) \text { METAKOM- } \\
\text { MUNIKATIVE, ANFØ- } \\
\text { RENDE }\end{array}$} & $\begin{array}{l}\frac{O G:, \text { ELLER:, MEN: }}{\text { LIGESOM: } E N D O G:} \\
\text { AT:, SAGT AF: }\end{array}$ & $\begin{array}{l}\text { og, samt, også, eller, men, alligevel, imid- } \\
\text { lertid, ikke desto mindre, på trods heraf, } \\
\text { imens, er, er det samme som, på samme } \\
\text { måde, i lighed hermed, også, endog }\end{array}$ \\
\hline \multirow{2}{*}{$\begin{array}{l}\left(2^{\circ}\right) \\
\text { NAR- } \\
\text { RATIVE } \\
\text { OMTALT } \\
\text { SITUA- } \\
\text { TION }\end{array}$} & TID & $\underline{S \AA}:, M E N S: ;$ EFTER AT: & \multirow{2}{*}{$\begin{array}{l}\text { så, derpå, dernast, da (adv), i det samme, } \\
\text { samtidig, x tid tidligere, førhen,: } \\
\text { "..." (kolon og anførselstegn) } \\
\text { thi, for, derfor, af den grund }\end{array}$} \\
\hline & $\begin{array}{l}\text { ÅRSAG } \\
\text { HENSIGT }\end{array}$ & $\begin{array}{l}\text { FORDI: } \text { DERFOR: } \\
\text { FOR AT: }\end{array}$ & \\
\hline \multicolumn{2}{|c|}{$\left(3^{\circ}\right)$ ARGUMENTATIV } & $\underline{E R G O: ; F O R:}$ & ergo, følgelig, altså, derfor, for, thi \\
\hline \multicolumn{2}{|c|}{$\begin{array}{l}\left(4^{\circ}\right) \text { INFORMATIO- } \\
\text { NELLE (KOMMUNIKA- } \\
\text { TIONSSITUATION) }\end{array}$} & $\begin{array}{l}\text { NEMLIG:, DVS: ALTSÅ:: } \\
\text { KORT:; FX: MULIGGØR: } \\
\text { M:), FORUDSAT: }\end{array}$ & $\begin{array}{l}\text { nemlig, altså, dvs., altså, kort sagt, fx, } \\
\text { forudsat }\end{array}$ \\
\hline
\end{tabular}

1. Hos nogle forfattere har konneksionerne betegnelser som additiv, alternativ, konsekutiv, men her noteres de med et kort ord der angiver typen, fx OG: DERFOR: eller MENS:. Læg mærke til at subjunktionaler, underordningskonjunktioner, bruges som notation (i UNDERSTREGEDE KURSIVE KAPITELER) for konneksionsrelationer, fx MENS: FORDI: selv om de ikke som subjunktioner kan være udtryk for denne relation i teksten, da der kun findes konneksioner mellem helsætninger. 


\section{Handling, tekstualisering og tekst}

\subsection{Tekstualiseringsformer}

Tekstualisering består i en integrering af meningen med sætninger der af afsenderen er sat efter hinanden. Denne integrering af sætninger sker på forskellig måde ved forskellige konneksionstyper. De sætninger der i interaktion kunne tælle som selvstændige meddelelser (4º-entiteter), degraderes ved tekstualisering med anførende konneksioner til emner $\left(1^{\circ}\right)$, ved narrative konneksioner til sagforhold $\left(2^{\circ}\right)$, ved argumentative konneksioner til udsagn $\left(3^{\circ}\right)$, og ved informationelle (eksponerende) konneksioner til meddelelser $\left(4^{\circ}\right)$. Ved hjælp af dette forhold kan man skelne mellem 4 forskellige former for tekstualisering, nemlig INKORPORERING (som babushkadukkerne) med anførende konneksioner, FUSION (som to klumper modellervoks) med narrative konneksioner, KOMPOSITION (som en konstruktion af legoklodser) med argumentative konneksioner, og ANALYSE (som Mandelbrotfraktalerne) af informationelle konneksioner.

(20) Tekstualiseringsformer

\begin{tabular}{|l|l|l|l|}
\hline INTEGRERINGSTYPE & KONNEKSIONSTYPE & & EKSEMPEL \\
\hline inkorporering (dukker) & anførende & $1^{0}$ & hun sagde + " "Tusind tak". \\
\hline fusion (modellervoks) & narrative & $2^{\circ}$ & hun vågnede + og sagde ... \\
\hline $\begin{array}{l}\text { komposition (klodser) } \\
\text { analyse (fraktaler })\end{array}$ & argumentative & $3^{\circ}$ & Hun må vare her + for hendes parfume \\
\hline
\end{tabular}

Af de fire kontekstualiseringsformer har inkorporering (med anførende konneksioner) og fusion (med dominerende narrative konneksioner) været eksemplificeret ved (10 og 8 Vejene omkring Pisa), mens komposition (med dominerende argumentative konneksioner)har været eksemplificeret ved (13 Hvem må slå hvem?). Her følger så et eksempel på analytisk tekstualisering som er domineret af de informationelle konneksioner nemlig $\therefore$, dvs $\therefore$ altså: kort $:$, fx:, muligg $\phi r:$ (M:), forudsat: der som en Mandelbrotfraktal har det samme mønster af NEMLIG:-relationer lige gyldigt hvormeget man zoomer ind.

11 Dong tabte britisk udbudsrunde ${ }_{21}$ VINDMøLLER. ${ }_{3}$ Dong Energy endte som taber $i$ en stor britisk ud-

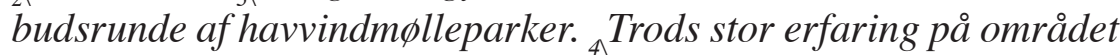
fik Dong ikke en af de udbudte zoner. ,"Det kommer som en stor 


\section{Ole Togeby}

overraskelse for os, ${ }_{0}$ for vi er de mest erfarne på dette område”, siger Andreas Krog, pressetalsmand hos Dong Energy. ${ }_{81}$ Han peger på, at Dong er involveret $i$ halvdelen af de store projekter på dette felt. ${ }_{9}$ Tidligere har Dong varet med også i nogle af de britiske projekter, der er blevet udbudt.

${ }_{10}$ Ritzau

Politiken 9. januar 2010:I, 12

$1 \backslash$ som er mærkværdig ved at have objektet i ikke-bestemt form, er som overskrift klart en meddelelse, som står i den informationelle konneksion NEMLIG: i forbindelse med selve teksten 2\-9\. 2\ er en slags rubrik, der står i samme konneksionsforbindelse med resten 3\-9\. 4\ er en specifikation af rollepladserne i udbudsrunde. $5 \backslash$ og $6 \backslash$ er forbundet med FOR:, og konneksionen mellem 5-6\og 7 7 er en SAGT AF:-konneksion; $8 \backslash$ er en NEMLIG:-specifikation af de mest erfarne. Status af 9\er tvetydig; er det dækket direkte tale således at det er noget Andreas Krog siger, eller er det en NEMLIG:-specifikation som afsenderen laver? I alle tilfælde er denne lille nyhedsnotits på ingen måde struktureret efter den omtalte situation med narrative konneksioner, men efter den informative relevans for modtagerne i kommunikationssituationen med informationelle

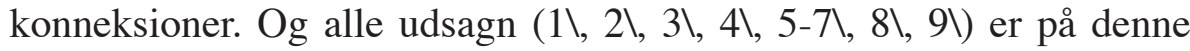
måde meddelt.

\subsection{Sammenfatning}

Der argumenteres her for at talehandlinger og teksthandlinger er to forskellige typer af handlinger. En talehandling er situering af et udsagn (proposition), som selv er udsigelse af et sagforhold (prædikation), som er omsagn (prædikat) om emner (nominale argumenter). En teksthandling er situering af en tekst, som er tekstualisering af en række paragraffer, der (som degraderede udsagn) er beskrivelser (ikke udsigelser) af sagforhold, som er omsagn om emner.

Situering sker ved angivelse af handlingens illokutionære kraft; tekstualiseringen sker ved integrering af rækker af paragraffer på grundlag af konneksionsforbindelserne mellem dem; udsigelse sker ved angivelse af sagforholdenes realitetsværdi; og omsigelse sker ved den grammatiske strukturering af ord til en sætning med subjekt og prædikat)

Den illokutionære kraft kan være konstativ, ekspressiv eller regulativ. Integreringen af paragraffer til en tekst kan ske ved universelle, anførende, narrative, argumentative eller informationelle konneksioner. Realitetsværdien kan være fremsat, benægtet, spørgende, hypotetisk, 


\section{Handling, tekstualisering og tekst}

kontrafaktisk eller ironisk. Omsagn kan være objektive, subjektive eller normative, og henvisningen til et emne kan være deiktisk, historisk, generisk eller fiktiv. En talehandlings type afhænger af konfigurationen af realitetsværdi, emnetype og omsagnstype; teksthandlingens type desuden af den dominerende konneksionstype.

Ved universelle konneksioner kan udsagn blive degraderet til hvad som helst. Ved anførende konneksioner degraderes udsagn til emner (entiteter af $1^{\circ}$ ). Ved narrative konneksioner degraderes udsagn til sagforhold $\left(2^{\circ}\right)$. Ved argumentative konneksioner transformeres udsagn til forbundne udsagn $\left(3^{\circ}\right)$ og ved informationelle konneksioner opgraderes udsagn til at blive meddelelseshandlinger $\left(4^{\circ}\right)$.

(22) Tekstualisering

\begin{tabular}{|c|c|c|c|c|}
\hline SITUERING & TEKSTUALISERING & UDSIGELSE & \multicolumn{2}{|c|}{$\begin{array}{l}\text { omsagn om sag- } \\
\text { forhold }\end{array}$} \\
\hline ILLOKUTIONER & KONNEKSIONER & $\begin{array}{c}\text { REALI- } \\
\text { TETVÆRDI }\end{array}$ & EMNE & OMS \\
\hline \multirow{4}{*}{$\begin{array}{l}\text { konstativ } \\
\text { fordring på sand- } \\
\text { hed }\end{array}$} & \multirow{3}{*}{$\begin{array}{l}\text { universelle: } \underline{O G, M E N, E L-} \\
\text { LER, LIGESOM, ENDOG, } \\
\text { anførende: } A T: \text { SAGTAF: } \\
\text { inkorporering: babushka }\end{array}$} & \multirow{2}{*}{ Fremsat } & deiktisk: 1.2.3.p. & \multirow{4}{*}{$\frac{\stackrel{0}{\sigma} .}{\frac{0}{0}}$} \\
\hline & & & historisk 3. p & \\
\hline & & & generisk 3 . p & \\
\hline & \multirow{2}{*}{ 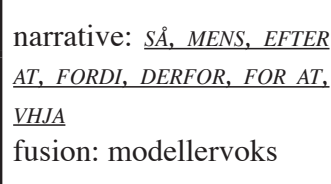 } & & fiktiv 1.2.3.p. & \\
\hline \multirow{2}{*}{$\begin{array}{l}\text { ekspressiv } \\
\text { fordring på ærlig- } \\
\text { hed }\end{array}$} & & spørgende & \multirow{2}{*}{$\begin{array}{l}\text { deiktisk: 1. per- } \\
\text { son }\end{array}$} & \multirow{2}{*}{$\frac{\mathscr{n}}{\stackrel{\sigma}{\Xi} .}$} \\
\hline & \multirow{3}{*}{$\begin{array}{l}\text { argumentative: } \underline{M E N}, \\
\frac{E R G O, F O R,}{\text { klodser }}\end{array}$} & \multirow{2}{*}{ hypotetisk } & & \\
\hline \multirow{5}{*}{$\begin{array}{l}\text { regulativ } \\
\text { fordring på retmæs- } \\
\text { sighed }\end{array}$} & & & 1. p: løfte tilbud & \multirow{5}{*}{ 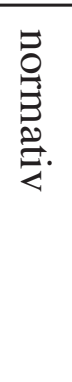 } \\
\hline & & \multirow[b]{2}{*}{ kontrafaktisk } & 2. p: påbud, bøn & \\
\hline & \multirow{3}{*}{$\begin{array}{l}\text { informationelle: } \\
\text { DVS, KORT ALTSA } A \text {, FX, MULIG- } \\
\text { GØR, FORUDSAT } \\
\text { analyse: fraktaler }\end{array}$} & & $\begin{array}{l}\text { upersonlig: er- } \\
\text { klæring }\end{array}$ & \\
\hline & & \multirow{2}{*}{ ironisk } & gensidig: aftale & \\
\hline & & & $\begin{array}{l}\text { generisk: regel, } \\
\text { lov }\end{array}$ & \\
\hline
\end{tabular}


Ole Togeby

\section{Litteratur}

Arndt, H. (2007). Talehandlinger - og anden sprogbrug, Dansklærerforeningen.

Austin, J. (1955, 1997). Ord der virker, Gyldendal.

Bachtin, M.M. (2009). “Talegenrer” i J.D. Johansen \& M. Lund Klujeff (red.), Genre, Århus Universitetsforlag.

Habermas, J. (1971, 2001). "Forberedende bemærkninger til en teori om den kommunikative kompetens" i C. Henriksen (red.) (2001). Can you reach the salt? Pragmatikkens klassiske tekster, Roskilde Universitetsforlag.

Lyons, J. R. (1977). Semantics 1-2, Cambridge University Press.

Reichenback, H. (1947, 1966). Elements of Symbolic Logic, CollierMacmillan.

Searle, J.R. (1969). Speech acts. An essay in the philosophy of Language, Cambridge University press.

Searle, J.R. (1976). A classification of illocutionary acts i Language in Society vol 5.

Sørensen, I. Z. \& O. Togeby (2001). Omvejene til Pisa. En fortolkning af Karen Blixen "Vejene omkring Pisa". Gyldendal.

Togeby, O. (2003). Fungerer denne satning? Funktionel dansk sproglaere. Gad.

Ole Togeby

Professor, dr.phil.

Nordisk Institut

Aarhus Universitet

norot@hum.au.dk 